\title{
'Daring Leaps' Construction of Meaning and Individual Agency in Career Change Narratives in the Media
}

\section{Kirsi LaPointe}

Post-doctoral researcher, Aalto University Business School, Finland

I Pia Heilmann'

Professor, Lappeenranta University of Technology, Finland

\begin{abstract}
The role of individual agency in crafting meaningful work has attracted increasing interest in recent studies of careers and working life. The purpose of this paper is to make visible the role of the media in reproducing and shaping understandings of careers and agency. By analyzing narratives of career change in the Finnish media, we identify three types of narrative and show how they construct meaningful careers by juxtaposing the past and present work in terms of setting, status, meaning, pace, and workload. Overall, these narratives depict a shift from traditional careers toward work that is concrete, meaningful, of lower status, and less hectic. Moreover, the narratives represent career changers as self-reliant heroes taking "daring leaps." Hence, we argue that the media reproduces individualistic assumptions of careers and reinforces the dominant, neoliberal ideal of self-responsible, autonomous subjects. We conclude by calling for alternative narratives that recognize the need for more meaningful careers but help strengthen agency in a less individualistic fashion.
\end{abstract}

\section{KEY WORDS}

Meaningful career / agency / career change / narrative / media

\section{Introduction}

ndividual agency in constructing meaningful careers has become highly topical in work life research and policy-making (Eteläpelto et al. 2013). Faced with the uncertainties and changing work life conditions, individuals are increasingly expected to be able to practice agency, that is, to make, and act upon, their own choices. At the policy level, this individualization of careers has become evident in neoliberal economic policies. Such policies emphasize individual responsibility and enterprise, along with the deregulation of markets and limitation of the governmental role (Roper et al. 2010). The Nordic countries have not escaped this trend, although the Nordic model has fared fairly well despite the neoliberal context (Kasvio et al. 2012).

In research, this emphasis on individual agency has received interest across various disciplines, such as adult education (Billett 2006, Eteläpelto et al. 2013, Fenwick 2006) and sociology (Järvensivu 2010, Julkunen 2008, Sennett 1998). In careers research, agency has been highlighted in the conceptualizations of careers as boundaryless and

\footnotetext{
${ }^{1}$ E-mail: pia.heilmann@lut.fi
} 
protean (Arthur and Rousseau 1996, Hall 2004, Tams and Arthur 2010). Such approaches depict the changes in labor markets as offering more space for individual agency, self-expression, and career customization (Sullivan and Mainiero 2007, Valcour et al. 2007).

Yet, the possibilities for agency in careers continue to spur debate. Many critics have called attention to the overly individualistic views of careers and the limited possibilities to create meaningful careers (e.g., Arnold and Cohen 2008, Dyer and Humphries 2002, Pringle and Mallon 2003). In particular, they have questioned the taken-for-granted, neoliberal ideal of a self-reliant subject who is personally responsible for his/her success (Roper et al. 2010). Hence, there have been calls for more interdependent notions of career agency (Tams and Arthur 2010) and for more contextualized analyses of the broader influences in the construction of careers and agency (Roper et al. 2010).

In this paper, our purpose is to make visible how the media produces and reproduces understandings of careers and agency. Although media is a powerful storyteller, both mirroring and shaping cultural meanings and norms (Fairclough 1995), its influence in career and work life studies has been largely ignored. Drawing on a discourse theoretical framework, we examine how meaningful careers and agency are discursively constructed in narratives of career change in the popular press. Based on a narrative analysis of 23 popular and professional magazine and newspaper articles in Finland, we ask first how the narratives construct assumptions about meaningful careers. Second, we examine how career changers in these stories are represented and how the stories construct their agency discursively. In other words, we are interested in the type of agency these texts assign to career changers, and not the agency of these individuals per se.

We contribute to the literature on careers, and work life studies more broadly, by showing how the media discursively reproduces particular understandings of careers and individual agency. Specifically, we describe three types of career change narratives and show in detail how they construct meaningful careers by juxtaposing the past and present career in terms of setting, status, meaning, pace, and workload. In general, the narratives paint a picture of a trend away from hectic, abstract work in offices toward concrete, tangible work at a lower status and pace. Moreover, we demonstrate how these narratives position career changers as independent and self-reliant heroes taking "daring leaps." Hence, we argue that the media, while offering inspiring alternatives to meaningful careers, reproduces individualistic assumptions of agency and reinforces the dominant neoliberal ideal of responsible, autonomous subjects in careers.

In the following, we first discuss the theoretical basis of our work. We then present our empirical material, narrative analysis methods, and the findings of our study. We conclude by reflecting on the main assumptions in these narratives and their consequences on the efforts toward more meaningful careers and the renewal of working life culture.

\section{A discursive approach to career meaning making in the media}

Ever since it was first introduced, the boundaryless career concept (Arthur 1994, Arthur and Rousseau 1996) has been influential in shaping understandings of career. Referring to the increasing permeability of career boundaries, this discourse has 
emphasized individual agency, mobility, and proactive, protean attitudes (Briscoe and Hall 2006). However, a number of critics have pointed out how boundaryless career theorizing has been overly individualistic and generalizing (Arnold and Cohen 2008, Dany 2003, Dyer and Humphries 2002, Pringle and Mallon 2003, Sullivan 1999). Hence, it reinforces career ideologies that assume careers as products of individual effort and paid employment as a primary source of one's identity (Richardson 2000). By constructing taken-for-granted assumptions about what is desirable and valued in careers, it also creates new exclusionary norms (Dyer and Humphries 2002). As Arnold and Cohen (2008) argue, such assumption creates a theoretically undersocialized and depoliticized view of careers.

The boundaryless career discourse has come under criticism also in respect to the political and economic ideologies it aligns with. Roper et al. (2010), based on a critical discourse analysis of academic texts on boundaryless careers, have pointed out that this discourse constructs and reinforces a broader neoliberal paradigm in two respects. First, it normalizes boundarylessness instead of critically evaluating its conditions or discussing alternatives. Second, it creates neoliberal subject positions where individual agency, individualism, and personal responsibility for careers are taken for granted.

In this paper, we join these scholars who have questioned the individualistic tenor of the boundaryless career discourse. We adopt a discourse theoretical perspective in order to examine how meanings and assumptions related to career are constructed in media texts. Our perspective is based on a constructionist perspective that pays attention to how social reality is assigned meaning and then negotiated and enacted in social practice and texts (Berger and Luckmann 1966, Burr 2003). From this perspective, language plays an integral role in creating realities through categories, discourses, and narratives. Instead of simply conveying neutral representations, language actively reproduces and constructs objects and phenomena, such as careers, via discourses. The importance of discourses lies in that they are constituted by, and constitutive of, social realities (Fairclough 1995). Moreover, they have a power to construct how we perceive, interpret, and understand reality. Of special interest are instances where discourses normalize certain issues as common sense. Hence, various texts and discourses have consequences and are inextricably linked to individuals and their sense-making and patterns of actions (Blustein et al. 2004, Cohen et al. 2004). By making available particular subject positions, discourses construct identities and empower and constrain agency (Davies and Harré 1990).

In the context of careers, narratives have an essential role in their discursive construction. Narratives are a fundamental form of knowledge by which human beings assign meaning to their actions, understand experience and temporality (Bruner 1986, Polkinghorne 1988). As career is understood as the sequences of a person's work experiences over time (Arthur et al. 1989), narratives are particularly relevant in making sense of careers (Cohen and Mallon 2001). However, our interest here is not in narratives as individual sense-making tools (cf. Cohen and Mallon 2001). Rather, we focus on cultural narratives as a distinct genre of discourse and on their role in producing and reproducing knowledge and taken-for-granted assumptions on careers. Such narratives impose a coherence structure on experiences with particular themes and plotlines (Linde 1993). In addition to assigning meaning to experiences, narratives also construct an understanding of who one is and how one is supposed to act. Therefore, cultural narratives legitimate and make desirable certain plots, or courses of action, while excluding others. This, in turn, has consequences on individuals and their agency. 
While there is some empirical research on discursive career meaning making (e.g., Coupland 2004, Duberley et al. 2006), it has focused predominantly on individual sense-making. A notable exception is the study by Roper et al. (2010) that analyzed how academic texts discursively constructed meanings of the so-called boundaryless careers. In this paper, we focus on media as an important, but largely ignored site for producing and reproducing cultural narratives and meanings of career. Mass media is a powerful storyteller that defines, interprets, and mirrors social reality (Fairclough 1995) and plays a role in collective sense-making (see Vaara and Tienari 2002). The press can never be truly objective but reproduces available discourses, social relations, and identities (Fairclough 1995). It has significant power in normalizing certain values and assumptions also in work life and, therefore, has consequences for how we understand our careers, what kind of meanings we assign to them, and how we craft our careers.

\section{Empirical data and method}

For our analysis, we collected stories of career change from a variety of Finnish magazines and newspapers from 2009 to 2012. Career change stories are fairly consistent in their approach across different types of publications, as our analysis also shows. As our focus was on voluntary career changes, we omitted stories where career change was an outcome of an unexpected job loss. In fact, whether career change is voluntary or involuntary is not necessarily a dichotomous choice but an empirical question. In our study, however, the cultural processes of accounting for career change are the focus of the analysis. Hence, the final decision as to whether an article was relevant for our study or not was done during the analysis. For example, we dropped a story that had to do with a short-term career change (a sabbatical).

The final sample consists of 23 stories (see Table I). Some of them were individual articles while some stories were featured within a general article on career change. We began the data collection in 2009 and added stories to our database as new stories emerged. Our purpose was to collect a sample of narratives across a wide range of the popular press. In 2012, we searched for additional narratives systematically via library databases and added three more into our sample. At this point, we felt we had reached a point where we had enough data to answer or research questions.

In using a discursive approach, we were not interested in the underlying motives or interests of the authors. Rather, we approached the texts as producing certain meanings and having consequences (Jokinen et al. 1999). As journalists tell stories, narrative analysis is a particularly suitable form of discourse analysis (Cotter 2003). We analyzed the stories first thematically by attending to what is said in the narratives and second structurally by focusing on how the content is delivered by particular language use and order (Riessman 2008). In addition, we paid attention to the evaluative aspects of the narrative which are central in conveying the point of the story. Such evaluation is rich in this type of narratives that seek to account for a disruption from an expected course of action. Hence, it also conveys embedded cultural assumptions (Linde 1993). Following this, we compared the narratives and looked for similarities and differences. As a result of our analysis, we constructed three narratives of career change that account for the change in different ways. Furthermore, we specified the main themes and linguistic choices by which the stories construct difference between the old and the new careers. 
Table I The career change stories analyzed with their sources

\begin{tabular}{|c|c|c|c|c|c|c|}
\hline$\#$ & Name & Before & After & Source & Genre & $\begin{array}{l}\text { Issue \# or } \\
\text { Date/Year }\end{array}$ \\
\hline I & Karin & $\begin{array}{l}\text { Biochemist, } \\
\text { researcher }\end{array}$ & $\begin{array}{l}\text { Baker, } \\
\text { entrepreneur }\end{array}$ & $\begin{array}{l}\text { Kodin } \\
\text { Kuvalehti }\end{array}$ & $\begin{array}{l}\text { Women's } \\
\text { magazine }\end{array}$ & $12 / 2009$ \\
\hline 2 & Veijo & $\begin{array}{l}\text { Telecom network } \\
\text { mechanic }\end{array}$ & Butcher & $\begin{array}{l}\text { Kodin } \\
\text { Kuvalehti }\end{array}$ & $\begin{array}{l}\text { Women's } \\
\text { magazine }\end{array}$ & $12 / 2009$ \\
\hline 3 & Kirsi & $\begin{array}{l}\text { Kiosk } \\
\text { salesperson }\end{array}$ & Café owner & $\begin{array}{l}\text { Kodin } \\
\text { Kuvalehti }\end{array}$ & $\begin{array}{l}\text { Women's } \\
\text { magazine }\end{array}$ & $12 / 2009$ \\
\hline 4 & Sari & Minister & MP & Me Naiset & $\begin{array}{l}\text { Women's weekly } \\
\text { magazine }\end{array}$ & 30.1 .2009 \\
\hline 5 & Risto & Bank director & $\begin{array}{l}\text { Head of nature } \\
\text { conservation } \\
\text { foundation }\end{array}$ & Etelä-Saimaa & Newspaper & 7.8 .2009 \\
\hline 6 & Pia & $\begin{array}{l}\text { Banking } \\
\text { executive }\end{array}$ & $\begin{array}{l}\text { Fashion retail } \\
\text { business owner }\end{array}$ & Talouselämä & $\begin{array}{l}\text { Business } \\
\text { magazine }\end{array}$ & $38 / 2009$ \\
\hline 7 & Mitro & Pastor & MEP & Apu & $\begin{array}{l}\text { Weekly } \\
\text { magazine }\end{array}$ & | 2.6.2009 \\
\hline 8 & Kenneth & $\begin{array}{l}\text { Advertising } \\
\text { executive }\end{array}$ & Chef & $\begin{array}{l}\text { Glorian Ruoka } \\
\text { and Viini }\end{array}$ & $\begin{array}{l}\text { Monthly gourmet } \\
\text { magazine }\end{array}$ & $46 / 2009$ \\
\hline 9 & Satu & TV director & Pastor & Anna & $\begin{array}{l}\text { Women's weekly } \\
\text { magazine }\end{array}$ & | 3.8.2009 \\
\hline 10 & Pauliina & $\begin{array}{l}\text { Kindergarten } \\
\text { teacher }\end{array}$ & Hairdresser & $\begin{array}{l}\text { Lappeen- } \\
\text { rantalainen }\end{array}$ & Local newspaper & 15.10.2009 \\
\hline 11 & Anne-Liisa & $\begin{array}{l}\text { Nokia lawyer and } \\
\text { executive }\end{array}$ & Coach & Anna & $\begin{array}{l}\text { Women's weekly } \\
\text { magazine }\end{array}$ & $14 / 2009$ \\
\hline 12 & Leea & $\begin{array}{l}\text { Nokia organiza- } \\
\text { tional develop- } \\
\text { ment specialist }\end{array}$ & $\begin{array}{l}\text { Antique furniture } \\
\text { preservation and } \\
\text { resale }\end{array}$ & $\begin{array}{l}\text { Helsingin } \\
\text { Sanomat }\end{array}$ & $\begin{array}{l}\text { National } \\
\text { newspaper }\end{array}$ & |.5.2010 \\
\hline 13 & Maria & Cleaner & $\begin{array}{l}\text { Rental income, } \\
\text { life in the country }\end{array}$ & $\begin{array}{l}\text { Helsingin } \\
\text { Sanomat }\end{array}$ & $\begin{array}{l}\text { National } \\
\text { newspaper }\end{array}$ & 30.11 .2009 \\
\hline 14 & Jarkko & $\begin{array}{l}\text { Lawyer in the } \\
\text { parliament }\end{array}$ & Writer & $\begin{array}{l}\text { Helsingin } \\
\text { Sanomat }\end{array}$ & $\begin{array}{l}\text { National } \\
\text { newspaper }\end{array}$ & 30.11 .2009 \\
\hline 15 & Hilkka & $\begin{array}{l}\text { Hospital labora- } \\
\text { tory worker }\end{array}$ & $\begin{array}{l}\text { Social psychol- } \\
\text { ogy studies in } \\
\text { university }\end{array}$ & $\begin{array}{l}\text { Helsingin } \\
\text { Sanomat }\end{array}$ & $\begin{array}{l}\text { National } \\
\text { newspaper }\end{array}$ & 30.11 .2009 \\
\hline 16 & Kerttuli & $\begin{array}{l}\text { Product manager, } \\
\text { pharmaceutical } \\
\text { industry }\end{array}$ & $\begin{array}{l}\text { Horse massage } \\
\text { therapist }\end{array}$ & Anna & $\begin{array}{l}\text { Women's } \\
\text { magazine }\end{array}$ & $32 / 2009$ \\
\hline 17 & Ritva & $\begin{array}{l}\text { Insurance } \\
\text { salesperson }\end{array}$ & $\begin{array}{l}\text { Chocolate } \\
\text { manufacturer, } \\
\text { entrepreneur }\end{array}$ & Ekonomi & $\begin{array}{l}\text { Professional } \\
\text { magazine for } \\
\text { business people }\end{array}$ & $9 / 2009$ \\
\hline 18 & Anna-Mari & $\begin{array}{l}\text { Brand executive } \\
\text { at Kone }\end{array}$ & $\begin{array}{l}\text { Small consulting } \\
\text { business }\end{array}$ & liris & $\begin{array}{l}\text { Women's } \\
\text { magazine }\end{array}$ & 2012 \\
\hline
\end{tabular}




\begin{tabular}{|c|c|c|c|c|c|c|}
\hline \# & Name & Before & After & Source & Genre & $\begin{array}{l}\text { Issue \# or } \\
\text { Date/Year }\end{array}$ \\
\hline 19 & Päivi & $\begin{array}{l}\text { Management } \\
\text { consultant }\end{array}$ & Nomad & Anna & $\begin{array}{l}\text { Women's } \\
\text { magazine }\end{array}$ & 2012 \\
\hline 20 & Toni & Tax consultant & Wine importer & $\begin{array}{l}\text { Life } \\
\text { Mandatum }\end{array}$ & $\begin{array}{l}\text { Corporate } \\
\text { magazine }\end{array}$ & I/2009 \\
\hline 21 & Tarja & Policewoman & Nurse & Me Naiset & $\begin{array}{l}\text { Women's } \\
\text { magazine }\end{array}$ & | 4.5.2009 \\
\hline 22 & Reija & $\begin{array}{l}\text { Communication } \\
\text { executive }\end{array}$ & Jazz singer & $\begin{array}{l}\text { Helsingin } \\
\text { Sanomat }\end{array}$ & $\begin{array}{l}\text { National } \\
\text { newspaper }\end{array}$ & I I.4.2010 \\
\hline 23 & Urpo & Translator & Verger & Telma & $\begin{array}{l}\text { Professional } \\
\text { magazine on } \\
\text { work life devel- } \\
\text { opment }\end{array}$ & $4 / 2012$ \\
\hline
\end{tabular}

In addition to explaining the reasons for career change, these narratives construct the character of the career changers and their moral worth. All of the narratives are success stories, and thus variations of the classic romantic or heroic storyline (Murray 1989), where the main character overcomes obstacles. Hence, the career changers are assigned the position of a hero who has succeeded in changing their career. In our analysis, we also looked at how these stories construct the main character and his/her agency. Such findings have relevance for understanding the prevailing expectations and responsibilities that are assigned to individuals in the context of work careers.

\section{Findings}

In this section, we present the findings of our analysis of the selected media texts. First, we show how career change is accounted for by drawing on three types of master narrative. Second, we analyze in more detail how these master narratives are put together by creating contrasts vis-à-vis certain aspects of the old and new career.

\section{Plotting the Change via Master Narratives}

The plot of the career change narrative focuses on explaining the change. Career change is always an interruption, an exception that calls for a culturally legitimate account. Even though the world of work is depicted as constantly changing, the underlying expectation is that of continuity and stability. Career change is not the norm, and hence it needs to be made sense of and accounted for. It is important to notice that we are not reading the media texts as conveying individual motives, such as push and pull factors. Rather, we are interested in how the meanings related to careers are discursively constructed in the media texts.

The main theme in all the narratives of career change is meaningful work. In fact, in all but one case the career change was aimed at making the content of the 
work more meaningful. The only exception is the case of a government minister who stepped down to continue as an MP: the nature of the work remained the same, but the responsibilities and hours were different. Although downshifting in terms of reducing the hours worked was evident in many narratives, in all the other cases it was combined with a change in the nature of the work. This does not mean that downshifting within one's current line of work is necessarily less common; career changes simply make better media stories. In the minister's case it is the high-profile nature of the job, the exceptionality of the move, and the gender of the individual that make it newsworthy, as we shall see later.

A more detailed analysis of the media texts revealed three types of narratives that we have labeled as follows: Dreamcatcher, Meaning-maker, and Downshifter (see Table II) narratives. This labeling conveys two significant aspects of the career change narratives: the reasoning behind the change and the focus on the individual career changer.

In the Dreamcatcher narratives, the new career stems from a hobby or interest that the career changer has had, often for a long time. In many cases, the new career has been a long-held dream that the career changer has finally acted upon. The reason why the change took place at this particular time was not always explicitly stated in the narratives, as the emphasis in them was on the interplay between the dream and the act of change and decision-making.

For example, Jarkko, a lawyer who had been working in legislation, simply made a decision to begin writing: "Then I decided that I will quit whining and begin writing." For Hilkka the time was opportune because her children had grown up, whereas parental leave gave Kerttuli the time to begin her own practice and business in horse massage therapy. Obviously, the new work is more meaningful or provides more enjoyment and inspiration than the old, but the narratives are not constructed to show what was wrong with the old work. Rather, the plot of the narrative is constructed around the idea of a deep interest, often a hobby, and the decision to make it into paid employment. An important aspect of dreams is the underlying assumption of dreams representing authentic and genuine aspects of the career changer's life. Whatever their work was before, it is characterized by lack and inadequacy. As a consequence, the individual is also assumed to be lacking something and incomplete as a person.

In the Meaning-maker narratives, the need to change is accounted for by the problems or dissatisfactions experienced in previous work. Although the Meaning-maker might have invested a lot in their past career and found it rewarding, due to changes in work or personal life that work no longer seems to meet the person's expectations. Career change is an effort to build and enact new meanings in one's work and to do work that feels good and right. For example, Karin had had a long international career as a scientist, but grew tired of the bureaucracy and applying for funding. She became an entrepreneur and started her own bread bakery in order to do something "concrete and meaningful." Pia, in turn, did not find her work as a private banker meaningless but was looking for something different. Her clothing business was supposed to be "just a hobby" to counterbalance "the number crunching." However, in the financial crisis she lost her job and ended up becoming a full-time entrepreneur.

In the Downshifter narratives the career change is explained by the need to have a less stressful and time-consuming job. Often this is coupled with the desire to do work that feels more meaningful. In five of the seven Downshifter narratives, the career 
Table II The master narratives: Dreamcatchers, Meaning-makers, and Downshifters

\begin{tabular}{|c|c|c|c|c|c|}
\hline$\#$ & Name & Sex & Age & Before & After \\
\hline \multicolumn{6}{|c|}{ Dreamcatchers } \\
\hline 8 & Kenneth & $M$ & 61 & Advertising executive & Chef \\
\hline 10 & Pauliina & $\mathrm{F}$ & - & Kindergarten teacher & Hairdresser \\
\hline 14 & Jarkko & M & 37 & Lawyer in the parliament & Writer \\
\hline 15 & Hilkka & $\mathrm{F}$ & 51 & Hospital laboratory & $\begin{array}{l}\text { Social psychology studies in } \\
\text { university }\end{array}$ \\
\hline 16 & Kerttuli & $\mathrm{F}$ & $\sim 30$ & $\begin{array}{l}\text { Product manager in pharma- } \\
\text { ceutical industry }\end{array}$ & Horse massage therapist \\
\hline 17 & Ritva & $\mathrm{F}$ & 37 & Insurance sales & $\begin{array}{l}\text { Chocolate manufacturer, } \\
\text { entrepreneur }\end{array}$ \\
\hline 20 & Toni & $M$ & - & Tax consultant & Wine importer \\
\hline \multicolumn{6}{|c|}{ Meaning-makers } \\
\hline 1 & Karin & $\mathrm{F}$ & 58 & Biochemist, researcher & Baker, entrepreneur \\
\hline 2 & Veijo & M & 53 & Telecom network mechanic & Butcher \\
\hline 3 & Kirsi & $\mathrm{F}$ & 42 & Kiosk salesperson & Café owner \\
\hline 9 & Satu & $\mathrm{F}$ & 54 & TV director & Pastor \\
\hline 7 & Mitro & $M$ & 50 & Pastor & MEP \\
\hline 21 & Tarja & $\mathrm{F}$ & 49 & Policewoman & Nurse \\
\hline 6 & Pia & $\mathrm{F}$ & 44 & Banking executive & Fashion retail business owner \\
\hline 22 & Reija & $\mathrm{F}$ & 47 & Communication executive & Jazz singer \\
\hline 23 & Urpo & $M$ & 56 & Translator & Verger \\
\hline \multicolumn{6}{|c|}{ Downshifters } \\
\hline 4 & Sari & $\mathrm{F}$ & 44 & Minister & MP \\
\hline 5 & Risto & $M$ & 57 & Bank director & $\begin{array}{l}\text { Head of nature conservation } \\
\text { foundation }\end{array}$ \\
\hline 11 & Anne-Liisa & $\mathrm{F}$ & 50 & Nokia lawyer and executive & Coach \\
\hline 12 & Leea & $\mathrm{F}$ & $\sim 40$ & $\begin{array}{l}\text { Nokia organizational develop- } \\
\text { ment }\end{array}$ & $\begin{array}{l}\text { Antique furniture preservation } \\
\text { and resale }\end{array}$ \\
\hline 13 & Maria & $\mathrm{F}$ & 40 & Cleaner & $\begin{array}{l}\text { Rental income, life in the } \\
\text { country }\end{array}$ \\
\hline 18 & Anna-Mari & $\mathrm{F}$ & - & Brand executive at Kone & Small consulting business \\
\hline 19 & Päivi & $\mathrm{F}$ & 41 & Management consultant & Nomad \\
\hline
\end{tabular}

changer had had a demanding job in business, one had worked as a minister and one as a cleaner. Anne-Liisa is a lawyer who had a long and successful career as an executive in Nokia. She first took a sabbatical as she was exhausted because of working at a hectic pace for years. She is also quoted as saying that she had no life outside her work, and felt that her daughter did not know who she really was. As she had been interested in ethical management for some time, she decided to quit her job and begin coaching managers. 
Maria's narrative is also about downshifting, but her story is entirely different from Anna-Liisa's. She worked as a cleaner, and yet she suffered from exhaustion because of the hectic pace at work. After preparing for it for a long time, she "got out of the rat race" and moved to the countryside. She lived on a small income from the rental properties she had invested in, having saved money from her small salary over the years. To make do, she grew her own food and raised sheep. Perhaps the most radical example of downshifting is the story of Päivi. Despite having a $\mathrm{PhD}$, a job as a management consultant, and the outward trappings of success, she had grown discontent with her life. Her work filled her life and yet her career, regardless of its success, felt meaningless. When she met a man with similar feelings, they decided to leave everything behind, get married, and travel the world together. Since then, for eight years, she has traveled around the world with her husband, doing odd jobs and simplifying her material needs.

The master narratives presented in this section tell us about the culturally acceptable and legitimate reasons for changing careers. Such reasons include long-held dreams, the search for more authentic, meaningful work, or the desire to slow down the pace of work and leave the rat race. In the next section, we look in more detail at how the narratives are constructed through a process of juxtaposing the past and present lives of the career changers.

\section{Constructing the Difference}

A key element in career change narratives is the construction of difference between the past and the new work. Depending on the type and length of the article there are variations as to how this is accomplished. In this section, we will look at the narrative means of constructing these differences, and analyze the consequences of such choices in promoting certain realities and values while questioning or glossing over others.

\section{Setting}

The place and nature of the work are sometimes vividly depicted to convey the nature of the change. A good example is Kerttuli's narrative of changing from a product manager's position in a pharmaceutical company to a horse massage therapist. While a couple of years earlier her marketing work took place in offices "in front of a computer screen, in meetings and on the phone" and all over the world, in the new position her work is outside or in barns and it is "dirty, greasy and risky." Although there are "sweat and smells" in her new job, this is not seen as a bad thing but rather a source of joy and pride. While the past job involved "abstract paper pushing and faceless communication over media technologies" the new work is real, tangible, and concrete, dealing with horses and saddles and allowing her to use her hands and her whole body.

In about a third of the narratives, the idyllic and romantic countryside is evoked even in cases where moving to the countryside is not a major driver of the plot. For example, Satu, who changed from being a TV director to being a pastor, got a position in the countryside. Moving to the countryside was not Satu's intention but the position was offered to her. Yet the imagery of the countryside is used in the narrative to create a contrast between "the hustle and bustle of Helsinki" and "the woodland of Kainuu" 
with its "beautiful" lake scenery and "a cozy, wooden church." At the same time, this contrast serves to construct a sense of the past and new work as being very different in their nature. In Maria's case, the move to the countryside was an integral part of a lifestyle change. She leaves behind "a consumerist lifestyle in the city" and life "in the suburb filled with apartment buildings" in favor of the countryside, "a log cottage at the edge of a forest" which she fixes up and where she takes care of her sheep. Overall, the new settings are simple, small scale, crafts oriented, human or local compared to cities, impersonal offices, large firms, and global travel. The two exceptions are Sari, who stepped down from a minister's position to be an ordinary MP, and Mitro, who left the church to work as a MEP (Member of the European Parliament).

In addition to the setting, the new types of work are often very concrete, or even mundane, as Kerttuli's work with horses well illustrated. In other similar narratives, the work is about bread, meat, cooking, chocolate, wines, antique furniture, and hair. Hence, the work is more physical and requires working with one's hands compared to the more abstract knowledge used for work in management, sales, TV, insurance, taxation, and so on.

\section{Status}

Another means of creating contrast and highlighting the nature of the career change is by describing changes in the status of the work. In the majority of the narratives, the change is considered a step down in status. Although it is not objectively self-evident as to what counts as having higher status, the narratives clearly construct such evaluations discursively. For example, Risto, who left a long career as a bank director to head a foundation to promote environmental protection, was considered to have stepped down. Although both of the positions are top executive posts, the position at the "big" bank is constructed as "high" and one that is usually "not given up voluntarily." Similarly, Anne-Liisa is described as having had "an exceptional career as a lawyer" and leaving behind "a successful career as an executive" in a successful, global firm (Nokia).

The change in status is also conveyed by simple juxtapositions of words or metaphors related to details of the work, such as the clothing worn. Hence, a former marketing and advertising executive who became a cook in his late fifties changed from " $a$ pinstripe suit" to "a chef's jacket." Satu switched from "TV director's stool to a pulpit." Similarly, Leea changed from "a jacket suit" and an office at a global firm to "overalls" in a dusty workshop in an old henhouse. Here the status difference is conveyed not only via the clothing, but also by the setting of the work. The settings described in the previous section can also, therefore, contribute to creating a status difference between the two careers. In the majority of cases, the past careers are presented as successful by talking about having a career and mentioning the titles (director, executive, banker, vice president, minister), their high remuneration, opportunities to travel all over the world, and big name employers. When these are contrasted with tangible, mundane objects of work and small, local settings, the status difference is clear. The status and value of past careers are also demonstrated by presenting the new work as "uncertain," "physical," "risky," "dirty," or showing how making a living is more difficult in the new work: "I get by," "money is always gone."

While the status of the new work may not be high according to the traditional markers of money, position, fame, and recognition, the loss of status in the previous 
careers is contrasted by highlighting the meaningfulness of the new work and the freedom gained, the latter pertaining to control over one's time, the pace of the work, and length of time at work. We will next describe how these juxtapositions are depicted in the narratives.

\section{Meaning}

It is hardly surprising that all of the narratives emphasize the meaningfulness of the new career as compared to the old. This is most clearly visible in the Meaning-maker narratives, where the entire plot is constructed around this contrast. Satu, 55, who used to work as a TV director, describes how work had "sucked her in" and how it had started to feel "empty." After finishing studies in theology that she had been previously doing, and deciding to become a pastor, her experience is characterized as having "an inner calling" and feeling like "a newborn." The new work is described as giving her "a sense of coming home," as if her "entire past life had been leading to this day." Meaning is thus constructed by assigning spiritual significance and by drawing on ideas of fate that have led to her new life. While such beliefs seem appropriate when considering the religious nature of her new career, similar beliefs are evident in wider discourses on callings and authenticity (Hall and Chandler 2005, Svejenova 2005).

Another example from the Meaning-maker narratives is that of Kirsi, 42, who ran a kiosk for 20 years and decided to start up her own café. She started to dislike the kiosk work as it had turned into "selling beer and lottery tickets." She thought this development was awful" and felt that "well-being derives from feeling that you are doing good work." In her own café, she feels like she is in her element, being able to do as she pleases and feeling so happy that she does not have "anything in the café that she does not want to sell."

In the Dreamcatcher narratives, the meaningfulness of the new work is also an important part of the plot. In these narratives, the description of the new work as a long-held dream, or having turned a hobby into a career, gives it more weight. As Linde (1993) has shown, career choices are considered as more legitimate when accounts of them have temporal depth. In addition, the meaningfulness of the new work is evident in the way it is described. Jarkko, the lawyer-turned-author, is quoted as describing the meaningfulness of being able to create as being "the finest thing in life after love." $\mathrm{He}$ feels he is "doing exactly what he wants in life" and hence, "the longing is gone." For example, Leea, who left her corporate job for her own furniture restoration business, is quoted as saying how "she gets carried away with some pieces of furniture and falls in love with them." In her case, as well as in several others, the ability to do "concrete" things, with "a clear beginning and end," and the sense of craftsmanship give meaning to one's work. In the cases where one has turned a long-time hobby or interest into a career, the meaningfulness of the change is already embedded in the assumption of hobbies and interests being meaningful by definition.

In the Downshifter narratives, the meaningfulness of the new work comes primarily from the escape from the rat race. In one case, the work itself has not changed significantly: this is Sari, an MP who stepped down from her minister's post, but who feels that both positions represent her dream occupation. In the other cases, the content of the new work is also a source of new meaning. For example, Anne-Liisa considers her new work 
as a coach a "mission" and herself as an "idealist" in promoting ethical management, in contrast to working previously under a type of productivity management that had resulted in "an endless race towards the unseen goal."

\section{Pace and workload}

Another way to contrast the new work against the old is related to the workload and pace. Interestingly, this works both ways: both the increase and decrease of workloads and pace are used to highlight the differences. In the Downshifter narratives, it is, obviously, a decrease in workload and the slower pace that account for the change. Sari now has "a freedom over her own schedule" and she has been able to "downshift." She is also "a more normal working adult" which in her case translates into someone who is able to be "more in touch with the children's everyday life." For the other two Downshifter women with children, the ability to balance work and family as a result of "slowing down" was also an important concern. As Leea is quoted as saying: "I did not want to be that mother who is the first to bring her children to daycare and the last to pick them up." Maria, who left her job as a cleaner and moved to the countryside to live on a meager rental income, describes how her days are leisurely in contrast to her previous life in the "rat race," working "at a killer pace that sucked joy and energy out of people."

In addition to the seven Downshifter narratives, there were nine narratives (representing both Meaning-maker and Dreamcatcher narratives) where reference to time and pace of work was made in the context of the new career. However, in these cases the workload had increased. Many of these individuals had become entrepreneurs, which often meant longer hours. Yet, as the downshifters showed, entrepreneurship can also be used to gain control over the hours worked and to work less. While the long hours can be considered a given in some discourses on entrepreneurship, in these narratives the function of such talk is to show how inspiring, interesting, and meaningful the new work is. Even if the work hours are long ("days tend to be long," "days may end up being 15 hours") and there is not enough time for sleep, hobbies, or friends, the message is that it is worth it. In addition, in some cases there is still the freedom to control the pace: "go riding a horse in the middle of the day" if you feel like it. Satu, the pastor, and Kenneth, the chef, who were not entrepreneurs, also described their days as hectic. "There has been a bell of a lot of work," as the pastor says-joyfully.

\section{Constructing the Character and Agency: Courageous and Independent or Morally Dubious?}

Plotting the changes and using different ways of contrasting the old and new careers both serve to construct the character or identity of the career changer and his or her agency. Via emplotment the career changer is made the focal actor of the narrative and through the construction of contrasts, the heroic nature of the act is emphasized. This is further supported by different ways of labeling the process and the act of making the change. For example, the act of change is described as "a jump," "a choice," "a decision," "an exceptional life change," or "a leap." In addition to naming the act, the action is described with similar vocabulary: she "made a life make-over," "he jumped in cold 
water to see whether he can swim," "I made a dream come true," she "dared to jump" or "dared to start from the beginning," "he made a stunt not everyone is up to" or "seized an opportunity."

What do these depictions make of the career changer? In the case of Kerttuli, she is described in the article as "courageous" and "independent," and this, in fact, is the point in all of the descriptions. Career change is an unusual move that requires courage and effort and hence makes a career changer into a kind of hero. In one article, various experts consulted said it directly: these people are "no sacrificing dupes" but "active and demanding actors" who question the current ways of working. The moral character of career changers is further pointed out by other people-those who simply "dream" or who "play it extremely safe."

While words such as "jump" and "leap" make it seem as if these career changes are easy and simple decisions, in most cases the process itself is characterized as being long and difficult. The decision has often been "brewing for a long time." For example, Risto had made a bet ten years prior to his career change that "he would leave the bankers' rat race before he turns 50 ." He lost the bet, since he was already 56 by the time he managed to make the decision "that he had been contemplating for so long." For Anne-Liisa, the sabbatical she took as she was "so exhausted" made her come to a final conclusion about starting a business in ethical management that she had been interested in "for a long time."

The difficulties in the process are also revealed in the ways the decision is legitimized. Interestingly, even though career change itself is idealized and the career changer turned into a courageous, independent actor, the need to legitimize the change shows how the decision is not always self-evident. The change is a break away from an expected course of action and hence needs to be accounted for.

In the article on Kerttuli, her "choice" is compared with the views of the younger generations who value meaningful work, independence, and flexibility. Younger generations have been described as being greedy and lazy, and it is against this charge that Kerttuli also needs to defend herself. She is quoted as saying how her generation cannot be criticized for being lazy, but rather that many are "working hard, starting up their own businesses, raising children and getting new degrees." A similar moral tone is in the expert argument provided in the same article that "not everyone can become craftsmen." The various "lifestyle entrepreneurs" and downshifters are therefore faced with the charge that they are just being selfish by not doing their fair share in working life: "if we slow down, the GDP decreases and Finland will fall out of the global competition."

Responsibility, status, and money are values that many career changers have given up. As in Risto's case, "a rare banker leaves voluntarily, particularly to become a director of foundation for nature preservation." Risto, however, is described as someone who does not do anything "by the book." The phrase "he will not miss anything of his previous position" also conveys that his high-status position represents a value that he wants to distance himself from.

Sari, who resigned from a ministerial post, is faced with an additional, gendered, charge in stepping down. Having always been "an A+ girl" who succeeds in everything, leaving the position could be seen as a failure. In emphasizing that "she was not tired or stressed out any more than expected," she counteracts the charge that she simply was not up to the task. The ability to spend more time with her children is emphasized and given priority: "I decided I will not make the most important decision of my life according to 
elections." Work, not children, needs to be flexible. Furthermore, her gender, combined with the high status of the position, makes this situation even more challenging: "again a woman opts out." It is as if she is failing the feminist fight for equality by opting out and proving that women cannot handle top management jobs. Therefore, there is a need "to remind" us that "she is not staying home or taking a sabbatical but continuing as an MP which is demanding work." In "Formula 1 terms," she is not taking "a pit stop" but simply "throttling down."

Money is mentioned explicitly in several narratives as many of the career changes have meant a significant pay cut or income insecurity. As in Jarkko's change from legal work to being a writer, he knew that his "standard of living will decrease." However, the financial aspect is not discussed extensively. When it is mentioned, it serves to highlight the courage and idealism of the decision.

Career changes also concern people other than the career changer, influencing the agency of the individual (Bosley et al. 2009). In those Downshifter narratives where family is a stated reason for the career change, this is explicit, but in many narratives there is no reference to how the decision has influenced the lives of family members or other close relatives. Sometimes the family represents the competing values that the career changer has given up. For example, Kerttuli sometimes thinks about returning to the pharmaceutical firm as "her husband thinks that steady working hours and income would not hurt." For Pauliina, her family was an important factor in the timing of the decision to go to school to become a hairdresser. As her son was not in school yet, it was "the perfect time" and "easy" to move to another town so that she could go to school. It is mentioned that her husband worked in the new town but there is no reference to any difficulties related to this arrangement.

\section{Discussion}

In this paper we have analyzed how the media discursively produces and reproduces understandings of meaningful careers and agency. We showed three types of master narratives that are used to describe and account for voluntary career change in the media: Dreamcatcher, Meaning-maker, and Downshifter. Moreover, we examined in detail how change is narrated by juxtaposing the old and new careers relative to the setting, status, meaning, and pace/workload. In addition to ideals of meaningful careers, these narratives reproduce and construct ideals about individuals: who one should be and how one should act in pursuing a meaningful career. In this section, we discuss the implications of our findings in relation to current understandings of careers and agency.

Our study contributes to the discussion on the nature of contemporary careers by highlighting the media as a site for constructing career meanings. Based on our analysis, the career change narratives in the media reinforce the ideal for crafting a career according to individual needs and personally defined criteria, as the literature on boundaryless and protean careers has previously indicated (Briscoe et al. 2006, Sullivan and Mainiero 2007, Svejenova 2005). While particular purposes and needs always vary, our media material offered a surprisingly homogeneous picture of desired careers. Broadly speaking, the changes were from hectic, big or business organizations and abstract knowledge work with high status in terms of position and/or rewards toward working with concrete things, such as people or food and having either a slower pace or more personal freedom. 
In this sense, these narratives are aligned with boundaryless career discourse that depicts a shift away from traditional, linear careers. While they celebrate dreams and authenticity, at the same time they downplay traditional careers and status markers. Yet they get their power from this contradiction-the denunciation of such values. This indicates how such traditional careers are still prevalent and even valued and, hence, career changes deviating from them are always seen as an exception. However, it is important to point out that our study cannot be interpreted as indicating a trend in career patterns more broadly. Rather, it shows such shifts in the prevalent career ideals as portrayed by the media. From this perspective, these media narratives portray a particular image of working culture and a striving toward more meaningful and less stressful lifestyles.

In addition to the images of meaningful careers, these narratives also produce understandings of the individuals and their agency. A key characteristic of the career change narratives is the central role given to the career changer. As the narratives are success stories, they are depicted as admired heroes. In this sense, the image of the individual is consistent with the boundaryless career literature and a protean orientation (Briscoe and Hall 2006). Our material shows how self-direction has become a presumed discourse and an ideal to strive for. Furthermore, in many cases the career changers are seen as resisting the alienating and intensifying tendencies of work in the current economic systems. These people are represented as committed to making the most of their lives and not sacrificing themselves to the economy and employers. As narratives always entail a moral evaluation of one's character, these narratives position career changers as acting morally vis-à-vis the working life. Yet, at the same time, some narratives reveal the other side of the coin. Career changers, particularly those who are downshifting, are also presented as negotiating with the charges of irresponsibility, laziness, and selfishness. This shows that there are still competing understandings of what counts as acceptable and legitimated career changes.

In making the career changers heroes, these narratives ignore contextual issues and constraints and gloss over the difficulties in making career changes. As a consequence, they end up reinforcing notions of individual agency, individualism, and opportunity in careers. Hence, we argue that the media reproduces not only the assumptions implicit in the boundaryless career discourse but ideological underpinnings related to the agency and responsibility of individuals. In their analysis, Roper et al. (2010) showed how similar assumptions were found in academic texts. They argued that these texts manifest neoliberal ideology that emphasizes individual rather than societal or organizational responsibility for career outcomes. In our study it is the genre of texts, that of personal career change narratives, that naturally puts the individual center stage. Yet, by normalizing and idealizing career change such narratives strengthen, and draw on, such ideologies and policies that place the responsibility for struggles in current working life on individuals. In this sense, the results of our study contribute more broadly to work life research on individualization of careers and the role of individual agency. Similar arguments for the individualization of work life problems have been made in studies of unemployment, stress, and burnout (e.g., Holmqvist 2009, Julkunen 2008). They show how such wider work life issues are medicalized and individualized as personal problems. In the case of career change narratives in the media, instead of pointing out what is wrong with the work life, career change narratives turn problems into personal life concerns and decisions. While the purpose of such narratives is undoubtedly to entertain and empower individual readers rather than to expose work life problems, it is important to pay attention to their problematic consequences. In addition to their ability 
to inspire, they also maintain exclusionary ideals that many people may find difficult to measure up to. As to the role of agency, this study joins earlier contributions in career studies (e.g., Tams and Arthur 2010) and adult education (e.g., Eteläpelto et al. 2013) that have emphasized the need for more contextualized research on the possibilities for constructing meaningful careers.

For future studies of career, this study suggests that closer attention should be paid to the various settings where cultural meanings of careers and ideologies are reproduced. Discursive analyses of other type of media coverage on working life issues would be helpful since media is so powerful in shaping discourses on careers and, hence, influencing individual sense-making. In addition to media, understandings of career and agency could also be examined in the increasingly popular self-help books and various forms of career coaching. This study also calls for new cultural narratives in the media and elsewhere to offer alternative, less individualistic views on promoting agency in crafting meaningful careers. Such narratives could focus, for example, on collective efforts to create meaningful work either inside or outside the current workplaces.

\section{References}

Arnold, J., \& Cohen, L. (2008) The psychology of careers in industrial and organizational settings: A critical but appreciative analysis. In G. P. Hodgkinson \& J. K. Ford (Eds.), International review of industrial and organizational psychology, vol. 23 (pp. 1-44). Chichester: John Wiley \& Sons, Ltd.

Arthur, M. B. (1994) 'The boundaryless career: A new perspective for organizational inquiry', Journal of Organizational Behavior 15(4): 295-306.

Arthur, M. B., Hall, D. T., \& Lawrence, B. S. (1989) Generating new directions in career theory: The case for a transdisciplinary approach. In M. B. Arthur, D. T. Hall \& B. S. Lawrence (Eds.), Handbook of career theory (pp. 7-25). Cambridge: Cambridge University Press.

Arthur, M. B. \& Rousseau, D. M. (1996) The boundaryless career. A new employment principle for a new organizational era. New York, NY: Oxford University Press.

Berger, P. L. \& Luckmann, T. (1966) The social construction of reality. A treatise in the sociology of knowledge. London: Penguin.

Billett, S. (2006) Work, subjectivity and learning. In S. Billett, T. Fenwick \& M. Somerville (Eds.), Work, subjectivity and learning. Understanding learning through working life. UNESCO-UNEVOC Technical and Vocational Education and Training Series 6, pp. 1-20. Dordrecht: Springer.

Blustein, D. L., Schultheiss, D. E. P., \& Flum, H. (2004) 'Toward a relational perspective of the psychology of careers and working: A social constructionist analysis', Journal of Vocational Behavior 64(3): 423-440.

Bosley, S. L. C., Arnold, J., \& Cohen, L. (2009) 'How other people shape our careers: A typology drawn from career narratives', Human Relations 62(10): 1487-1520.

Briscoe, J. P. \& Hall, D. T. (2006) 'The interplay of boundaryless and protean careers: Combinations and implications', Journal of Vocational Behavior 69(1): 4-18.

Briscoe, J. P., Hall, D. T., \& DeMuth, R. L. F. (2006) 'Protean and boundaryless careers: An empirical exploration', Journal of Vocational Behavior 69(1): 30-47.

Bruner, J. (1986) Actual minds, possible worlds. Cambridge, MA: Harvard University Press.

Burr, V. (2003) Social constructionism (2nd ed.). London, New York, NY: Routledge.

Cohen, L., Duberley, J., \& Mallon, M. (2004) 'Social constructionism in the study of career: Accessing the parts that other approaches cannot reach', Journal of Vocational Behavior 64(3): 407-422. 
Cohen, L. \& Mallon, M. (2001) 'My brilliant career? Using stories as a methodological tool in careers research', International Studies of Management and Organization 31(3): 48-68.

Cotter, C. (2003) Discourse and media. In D. Schiffrin, D. Tannen \& H. E. Hamilton (Eds.), The handbook of discourse analysis (pp. 416-436). Oxford: Blackwell Publishers.

Coupland, C. (2004) 'Career definition and denial: A discourse analysis of graduate trainees' accounts of career', Journal of Vocational Behavior 64(3): 515-532.

Dany, F. (2003) 'Free actors' and organizations: Critical remarks about the new career literature, based on French insights', International Journal of Human Resource Management 14(5): 821-838.

Davies, B. \& Harré, R. (1990) 'Positioning: the discursive production of selves', Journal of the Theory of Social Behavior 20: 43-65.

Duberley, J., Cohen, L., \& Mallon, M. (2006) 'Constructing scientific careers: Change, continuity and context', Organization Studies 27(8): 1131-1151.

Dyer, S. \& Humphries, M. (2002) 'Normalising workplace change through contemporary career discourse', Advances in Mental Health 1(3): 158-169.

Eteläpelto, A., Vähäsantanen, K., Hökkä, P., \& Paloniemi, S. (2013) What is agency? Conceptualizing professional agency at work. Educational Research Review 10: 45-65.

Fairclough, N. (1995) Media discourse. London: Edward Arnold.

Fenwick, T. (2006) Escaping/Becoming subjects: learning to work the boundaries in boundaryless work. In S. Billett, T. Fenwick \& M. Somerville (Eds.). Work, subjectivity and learning. Understanding learning through working life. UNESCO-UNEVOC Technical and Vocational Education and Training Series 6, pp. 21-36. Dordrecht: Springer.

Hall, D. T. (2004) 'The protean career: a quarter-century journey', Journal of Vocational Behavior 65(1): 1-13.

Hall, D. T. \& Chandler, D. E. (2005) 'Psychological success: When the career is a calling', Journal of Organizational Behavior 26(2): 155-176.

Holmqvist, M. (2009) 'Medicalization of unemployment: Individualizing social issues as personal problems in the Swedish welfare state'. Work, Employment \& Society 23(3): 405-421.

Jokinen, A., Juhila, K., \& Suoninen, E. (1999) Diskurssianalyysi liikkeessä. Tampere: Vastapaino.

Julkunen, R. (2008) Uuden työn paradoksit. Keskusteluja 2000-luvun työprosess(e)ista. Tampere: Vastapaino.

Järvensivu, A. (2010) Tapaus työelämä ja voiko sitä muuttaa. Tampere: Tampereen Yliopistopaino Oy.

Kasvio, A., Gonäs, L., \& Skorstad, E. J. (2012) 'In search of the Nordic working life model: Introduction to the thematic issue', Nordic Journal of Working Life Studies 2(4): 1-19.

Linde, C. (1993) Life stories: The creation of coherence. New York, NY: Oxford University Press.

Murray, K. (1989) The construction of identity in the narratives of romance and comedy. In J. Shotter \& K. J. Gergen (Eds.), Texts of identity (pp. 176-205). London: Sage Publications.

Polkinghorne, D. E. (1988) Narrative knowing and the human sciences. Albany, NY: State University of New York Press.

Pringle, J. K. \& Mallon, M. (2003) ‘Challenges for the boundaryless career odyssey', International Journal of Human Resource Management 14(5): 839-853.

Richardson, M. S. (2000) A new perspective for counsellors: From career ideologies to empowerment through work and relationship practices. In A. Collin \& R. A. Young (Eds.), The future of career (pp. 197-211). Cambridge: Cambridge University Press.

Riessman, C. K. (2008) Narrative methods for the human sciences. Thousand Oaks, CA: Sage Publications. 
Roper, J., Ganesh, S., \& Inkson, K. (2010) 'Neoliberalism and knowledge interests in boundaryless careers discourse', Work, Employment and Society 24(4): 661-679.

Sennett, R. (1998) The corrosion of character: The personal consequences of work in the new capitalism. New York, NY: W.W. Norton \& Company.

Sullivan, S. E. (1999) 'The changing nature of careers: A review and research agenda', Journal of Management 25(3): 457-484.

Sullivan, S. E. \& Mainiero, L. A. (2007) 'Kaleidoscope careers: Benchmarking ideas for fostering family-friendly workplaces', Organizational Dynamics 36(1): 45-62.

Svejenova, S. (2005) “The path with a heart': Creating the authentic career', Journal of Management Studies 42(5): 947-974.

Tams, S. \& Arthur, M. B. (2010) 'New directions for boundaryless careers: Agency and interdependence in a changing world', Journal of Organizational Behavior 31(5): 629-646.

Vaara, E. \& Tienari, J. (2002) 'Justification, legitimization and naturalization of mergers and acquisitions: A critical discourse analysis of media texts', Organization 9(2): 275-304.

Valcour, M., Bailyn, L., \& Quijada, M. A. (2007) Customized careers. In H. Gunz \& M. Peiperl (Eds.), Handbook of career studies (pp. 188-210). Thousand Oaks, CA: Sage Publications. 